\title{
A Multifaceted View of CEO Compensation and Performance: A Case Study
}

\author{
John Nirenberg \\ Stamford International University
}

\begin{abstract}
This case addresses CEO pay, a topic that annually stimulates the question of whether or not executive compensation is based on performance or something else and why it is so high in absolute terms. The societal impact of the new class of extremely high-paid executives in the United States inflames resentment among workers, widens an already unfathomable distance between those at the top and the rest of us, and endangers the social amity among citizens. Positive social change might result from the justification and recalibration of salaries to align more sensibly with actual differences in experience, knowledge, and talent among all workers. However, first, we must become aware of the impact of differences that now alienate much of the working class population from workplaces that enable such a wide salary gap between top executives and average workers. This case is designed to help learners think through the various elements constituting the excessive CEO pay issue.
\end{abstract}

Keywords: executive compensation, CEO, CEO pay, pay, income disparity, organizational justice, executive performance measurement, agency theory, labor market, CSR (corporate social responsibility), extrinsic motivation

\section{Introduction}

\section{The Case Overview and Purposes}

Each spring, as new compensation packages are announced, a question arises about the widening disparity between top-executive compensation and that of average workers. According to the American Federation of Labor and Congress of Industrial Organizations (AFL-CIO, 2018), the CEOto-worker pay ratio was 347:1 (para. 1). The Stop and Think questions embedded throughout the case are to stimulate learners' thinking about the various issues raised along the way, which include the nature of the neoliberal economic system in the United States, pay disparity, economic justice/fairness, performance measurement, the economic value of labor, and the role of personal responsibility and negotiation skill on one's compensation, and agency theory.

\section{Learning Outcomes}

By completing this case, learners will have an understanding of the multifaceted issues surrounding executive pay. By focusing on CEO compensation in particular (because top-tier managers' salaries are usually geared to the CEO's), students will understand (a) the challenges of defining and measuring executive performance, (b) the disparity between the CEO and average workers in the organization, (c) the underlying values that allow what most observers call excessive compensation, and (d) the impact this has on individuals, organizations, and society. Most importantly, the primary outcome of using this case is that learners will develop their own reasoned position on this situation and be able to defend it with references from the literature. 
This interactive case asks learners to think about CEO compensation from various perspectives and to determine what they think and why about the many aspects of this issue. One question that remains unanswered in this case, which students of management will enjoy tackling, is "How is executive performance measured?" Likewise, a second key challenging question is "If boards of directors are paying for performance, why is there an inverse relationship between the two?" (Cooper, Gulen, \& Rau, 2014, p. 2). Both of these questions can also serve as short research projects for learners at all levels.

\section{The Case}

There are about a baker's dozen Dunkin' Donuts shops along the New Jersey Routes 27 and 21 corridor that parallels I-95 for a few miles until the interstate then heads into New York City. On any given day, Maria Fernandez worked a shift in up to three of those donut shops. She was very responsible and did not want to be late to work, so she kept a fuel can on the backseat of her car because she occasionally ran out of gasoline, at least according to a report in The New York Times (Swarns, 2014). The 32-year-old made ends meet constantly running herself from one donut shop to another until she was found dead in her car while resting on an August day between shifts. An autopsy report said fumes from the fuel can killed her (Haydon, 2014). Jobs like hers start at the minimum wage and hardly improve for years. The minimum wage in New Jersey for 2018 is $\$ 8.60 / \mathrm{hr}$ (Minimum-wage.org, 2018). If Maria could have worked three 8-hr shifts 7 days a week at today's wage, which would be physically impossible, of course, it would have taken her 118 years to earn the $\$ 5,355,035$ that Nigel Travis, CEO of Dunkin Brands Group, made in 2016 (AFL-CIO, 2018; last available data).

Stop and Think: What is your reaction to this situation? How would you explain why this situation exists where Nigel made 177 times Maria's salary if she worked two complete shifts 5 days a week? If you were Maria's friend, and you were having coffee with her before her tragic end, how would you assess her situation? What advice would you have given her, if any? Is there any reasonable explanation Maria could have provided regarding her particular employment situation other than needing the money?

Other similarly dramatic stories emerge almost daily about people barely surviving in the present economic climate, even though unemployment is low. Margaret Mary Vojtko, 83, was an educator who taught at Duquesne University for 25 years. As an adjunct professor, she contributed to the growth and development of perhaps thousands of students as they prepared for exciting careers and fulfilling lives. That was her passion. One mid-September day, she was found sprawled on her lawn, dead of a heart attack; her dilapidated home, a sad commentary on her economic status, loomed behind her. She was living on $\$ 10,000$ a year from her job as an adjunct French teacher. She had been struggling on that salary for several years but refused all efforts at charity and insisted on taking care of herself. Days before her death, the university told her she would not get a contract renewal. In her death, Margaret Mary, much as Maria Fernandez, became the voice of part-timers everywhere. Sanchez (2013) estimated that “...today, $75 \%$ of college instructors are adjuncts making between $\$ 20,000$ and $\$ 25,000$ a year ..." (1:38), this at a time when university presidents are breaking the million-dollar-a-year salary threshold and the student loan crisis reflects the everrising cost of tuition. 
Stop and Think: Maria and Margaret Mary are two very different people; one less formally educated and one with all the credentials to teach at a prestigious university, yet both were caught in economic hardship and marginalized, basically struggling with disposable jobs indicative of how little they were valued. How would you explain Margaret Mary's situation and how she ended up destitute at age 83? Hint: Embedded in these two vignettes are potential issues of gender, race, age, education, and the restructuring of jobs now occurring throughout both blue- and white-collar occupations. How might the university explain its actions? In light of her dismissal from Duquesne, what alternative(s) did Margaret Mary face? What do you see in these two people that speaks to your own life? How will you attempt to secure your economic future upon graduation and into old age to avoid facing these kinds of hardships? Does the larger society have a say in this, or is it entirely your responsibility? Do organizations have a role to play in the wellbeing of those who work for them? If not, explain why. If so, explain what that role should be.

Reminder: This interactive case is about CEO compensation and performance, but ultimately, it is about the growing disparity among average workers and top executives. In addition, you will have an opportunity to consider ideas about the supply and demand of labor, performance incentives, motivation, competing values, organizational citizenship, and corporate social responsibility. The key purpose of this case is to stimulate your thinking about major issues facing business today around workforce compensation, especially that of CEOs, and its impact on individuals, the organization, and society. Because it is an interactive case, from time to time, you will be asked to stop and think (as you have been above) and to gather your thoughts about each topic. There are no right or wrong answers, but you should be prepared to discuss your answers and your reasoning in class or in a paper, so give each question some thought before reading further.

\section{The Context of Pay Disparities}

The CEO-pay-to-worker ratio in the companies comprising the Standard and Poor's 500 stock index has been growing through good times and bad over the last 50 years. In 1965, it was 20:1, while today, it has ballooned to $347: 1$. According to the AFL-CIO (2018) Executive Paywatch that tracks these data annually, this is an improvement over last year and was better still than in prior years when the widest personal ratio hit 1,951:1 at Discovery Communications (Masunaga, 2015). Yet, even though worker productivity has increased dramatically over those 50 years, workers' wages have not, and since 2000, they have been flat, according to the Economic Policy Institute (2018), an economic think tank in Washington, DC. This kind of pay gap between top executives and everyone else influences the character of the economy and standard of living for the majority of people.

Further, the underlying causes of the disparity have not been addressed except with outrage. Some people want to reign in the salaries of top managers, while others think this is a natural outgrowth of the competitive marketplace and the workings of the capitalist system, not a social problem. 
Stop and Think: What is your perspective on this? Is this just the way the economy works and an indicator of the talent of the CEO and his negotiating skills (McGregor, 2017; only $6.4 \%$ of the Fortune 500 CEOs are female)? Or do you think adjustments can be made, such as raising the minimum wage to what is considered a living wage so people like Maria will not have to take three or four jobs to make ends meet, which is the result of being paid an inadequate minimum wage and not a living wage? ${ }^{1}$

\section{The System}

The debate among advocates and detractors of regulating or limiting "excessive CEO pay" raises fundamental concerns about the nature of companies themselves. As private property, no matter how big they are or the number of shareholders they represent, many argue they should be left alone to decide whatever compensation they are willing and able to offer a CEO. On the other hand, some people ask, what if large corporations are treated as societal instruments, or even public utilities, subject to regulatory intervention including setting the upper limits of compensation? Just as a minimum wage is set, should a maximum wage be set? Should no limits be set, but marginal tax rates be used that might increase to reach $100 \%$ at the highest bracket determined by Congress? In 1977, Peter Drucker, who is sometimes called the father of modern management theory, suggested that a ratio be established between the highest and lowest paid employee. He suggested a ratio of 20:1 or even 30:1, about the same level in practice in the 1970s.

\section{Core Values and the Market}

The debate also touches on core values. Are we a nation of individuals and families or a nation of one people in shared communities? In terms of the individual relationship to the organization, should employee compensation reflect each person's financial situation (e.g. number of children one has, or disability, or student debt) or just labor market forces, merit, and performance? Or should other factors-based on an artificial internal determination consisting of job value, unemployment rates, geographic mobility, and the ability to resettle or not or sheer economic power determined by local competitors-influence worker compensation? CEO compensation is not similarly constrained. The market is theoretically global, but candidates are employed and establish their legitimacy for a place in the strictly limited market encompassing only one or two levels of executive jobs below the CEO in organizations of equal or larger size. One study showed that the so-called market for executive talent really does not operate as a true market because the number of candidates is artificially low due to experience requirements, the tendency to promote from within (upwards of $80 \%$ according to the High Pay Centre, n.d.), and the lack of transparency. Further, the tendency to "benchmark" against industry competitors and demonstrate to investors that one has the best CEO by virtue of having and paying the highest relative salary keeps raising the stakes in the compensation game-a psychologically driven process, not a market one. Plus, according to Lorsch and Khurana (2010), the idea of negotiating one's compensation package belies the existence of the market and cannot explain the "make whole" provision in new CEO contracts that guarantees any compensation lost by moving

\footnotetext{
${ }^{1}$ A living wage is the idea that every full-time job should be sufficient for one to live on without needing a second job or public assistance. Seattle's 2014 vote to raise the city's minimum wage to $\$ 15 / \mathrm{hr}$ was an attempt to ensure that its citizens earn a living wage and are able to participate economically in the community. The living wage in Seattle was calculated by the Massachusetts Institute of Technology to be $\$ 13.34$ for one adult (Living Wage Calculator, 2018); all calculations of a living wage are made on the basis of local costs.
} 
to the top spot from another company or the provision of a "golden parachute" - a payment to the successful candidate if he is forced to leave the company for underperforming or simply retires.

In a famous example of this, when Jack Welch retired in 2001, he received $\$ 417,361,902$, a New York apartment, box seats at Red Sox games, and $\$ 9,000,000$ a year for the rest of his life (CNN Money, 2002). All of this accrued to the man once called "Neutron Jack" and derided in the business press for the number of people laid off at GE during the early years of his tenure. These benefits are not the result of market conditions but hard negotiating. In many cases, such as when someone leaves in disgrace or is pushed out, the payout, negotiated or not, still remains unconscionable to the working person. According to Wile (2012),

Stanley O'Neal presided over Merrill [Lynch's] collapse in the subprime crisis. Board members allowed him to retire in 2007, but though he forfeited pension, perks and deferred compensation worth $\$ 54$ million, he walked away with equity profits worth over $\$ 160$ million. (p. 9)

For comparative purposes, both Jack Welch and Stanley O'Neal received more money when they left their organizations than the American people pay their national legislative, judicial, and executive leaders in a year. The total salaries of the U.S. president, vice president, all 535 members of Congress, the 15 cabinet members, all nine Supreme Court justices, and the governors of the 50 states combined come to $\$ 105,000,000$ (Janssen, 2018).

Stop and Think: Not only is the CEO-worker disparity glaring, but what do you think of the kind of golden parachutes executives have been given whether or not they left on the crest of their success or shamefully, having contributed to one of the biggest economic crises in American history? If you were a board member in either Jack's or Stanley's case, how would you have acted? Would you have been in favor of or opposed to their exit packages? Please explain your answer.

Given the nature of the economy, questions about justice, fairness, and equity in the current economic climate are not priority issues and may seem irrelevant because of the little attention they receive in the national mass media. Indeed, under the current rules of the game, it seems our society is one in which it is each person for him- or herself. It is solely a matter of one's having the right parents or the right connections and the ability to be in the right place at the right time-and the right education helps, too, of course. In that regard, luck comes into play as a major influence in the compensation sweepstakes.

According to Cremers and Grinstein (2014), pay for luck occurs when a CEO's compensation is tied to factors outside his or her control. For example, they point out that when personal performance is tied to industry performance, it is a matter of luck because the CEO can rarely, if ever, control the future of an industry.

Stop and Think: Is this just the way the world works, reflecting the "true" nature of society, or are the people behaving in accordance with the rules that govern their economic lives? Explain your position and support it with additional sources. 


\section{Psychological Factors}

Besides working in a compensation system that is exaggerated by the magnitude of both competitive forces among a relatively few upper-level managers, and the size of the companies able to pay enormous salaries, psychological factors also combine to make salary more symbolic than a strictly economic decision for a company. Clearly, we connect size of company with presumed stature and with CEO compensation. We have come to expect large salaries for the CEO given the economic impact, social utility, presence in the community, and the power and responsibilities of the position holder. Doug McMillon, the CEO of Walmart, made $\$ 22.4$ million in 2016 (Bose, 2017). According to Walmart's corporate website, "Walmart operates over 11,700 stores under 65 banners in 28 countries and e-commerce websites. We employ approximately 2.3 million associates around the world-1.5 million in the U.S. alone" (Walmart, 2018, "Our Business," para. 1). If each of those 1.5 million "associates" was the breadwinner for two others, 4.5 million people would be dependent on the success of Walmart for their economic livelihoods. That would make the population of Walmart larger than that of the United States at the time of its independence from the United Kingdom. Given the size of Walmart, the biggest retail chain in the world, one would expect the CEO salary to be significant. By way of contrast, the U.S. government employed 9,100,000 people in all categories (full and part time including Department of Defense; Gunter, 2017, para. 3) and the CEO (i.e., the president) made only $\$ 400,000$ plus an expense account of $\$ 50,000$, a $\$ 19,000$ entertainment account, $\$ 100,000$ travel account, plus a residence for use while in office. A new associate at Walmart would need to work 1,120 hr to equal a single hour's pay for CEO Doug McMillon.

As the relative position of one individual is measured against another in the same industry, much distortion occurs in assessing one's true worth, if it is possible to determine at all—especially when one is chosen without any experience as a CEO. Charter's Thomas Rutledge, the highest paid CEO in 2016 , was given a $499 \%$ raise from his 2015 salary of $\$ 16.4$ million (Huang \& Russell, 2017). Revenues were only 3.9\% higher than in 2016 (Charter Communications, 2018).

Stop and Think: If you were a Charter board member, how might you consider the success or failure of Rutledge's tenure at Charter so far? How would you justify the $499 \%$ pay raise? Do you think his current compensation is high or low? What other outcome measures might be important to the board in assessing his success or failure? Once you have answered these questions, consider this: The stock price rose from $\$ 168$ to $\$ 298$ per share from January 2016 to January 2017 . How would that influence your decision?

\section{Performance}

The highest performing professional sports figures and highest grossing box-office celebrities in Hollywood earn astronomical salaries inclusive of minimums, percentages, endorsements, and other financial rewards for their efforts. Some actors' incomes in a single year dwarf those of CEOs; critics cite the ephemeral nature of their work and the fact that, in the big scheme of things, they have less of an impact than, for example, Rutledge. But the reach of a single movie can be global, not only in selling tickets, but in merchandising, employment, and inspiration. Clearly, the economic impact of Black Panther (Coogler, Feige, \& Grant, 2018) has been huge. Domestic ticket sales alone hit $\$ 600$ million and rising, as of April 1, 2018, early in its life cycle. With international sales, the total surpassed $\$ 1.2$ billion, making it one of, if not the, biggest box office hits of all time according to Box Office Mojo (2018). The lead actor, Chadwick Boseman, is poised to become one of the biggest action stars to rival Robert Downey, Jr., star of the Avengers and Ironman series who made $\$ 75$ million for 
the year ending in June 2014 (Pomerantz, 2014). He made even more for the Avengers: Age of Ultron (Whedon \& Feige, 2015) movie, the last in the series but part of the Marvel cosmology that consists of multiple characters and storylines that fuel a huge action adventure cinematic universe (for complete details, see "List of Marvel Cinematic Universe Films," n.d.). Is performance measured differently for actors? Is the box office draw really just a matter of one's personal appeal? No doubt it has something to do with it, but how would you separate that from the writing, the production, the long familiarity with the characters and story line drawn from Marvel Comics? Now that Chadwick is the hero, his bargaining power, especially because the financial results were so great, is strengthened, leading some to claim he, like Downey, will make upwards of $\$ 100$ million next year.

Sean Peyton, head coach of the New Orleans Saints football team, earns $\$ 8$ million a year. He is the third highest paid coach in the United States (Moton, 2018), yet his team wobbles between great and terrible each year. The Saints have not been in a Super Bowl since 2010 and didn't make the playoffs again until 2017, when they lost. On the strength of the Super Bowl victory, he was able to skirt the damaging impact of his 1-year suspension during the bounty scandal in which some team members were paying other team members to disable a key opposition player. What are his performance measures here, and can they be isolated from the effectiveness of his team and the ability of opponents?

Cristiano Ronaldo is the world's highest paid athlete, making $\$ 93$ million in 2017 , the year the Fédération Internationale de Football Association named him athlete of the year for the fourth consecutive year. He has led teams to conference victories for years and Real Madrid has agreed to pay him $\$ 50$ million for each of the next 4 years. His performance is indisputable; it speaks for itself ("Profile: Cristiano Ronaldo," 2017).

And CEOs? It has been suggested all along that some CEOs are able to negotiate fantastic compensation packages either because of past successes or even the promise of future successes. How is success actually measured? Stock price? Market share? Profits? Return on investment? Profits per employee? Some combination of these measures? Something else? Ron Johnson was the chief of retail operations at Apple who surprised everyone by opening stores in major cities after other computer companies closed theirs. Everyone doubted the plan, but it became one of the most successful innovations in tech sales. Based on this success, JCPenny wooed him to work his magic on its slumping retail business. But, after only 18 months on the job, he was fired; his performance was seen as a disaster from the outset. Why do you suppose a superstar retailer had such a fantastic failure?

Considering the large salaries companies are willing to pay, it turns out, according to Lin, Kuo, and Wang (2013) "... that firm size appears to be the most important determinant of CEO compensation and that there is a general lack of linkage between pay and performance" (p. 27). A year later, Cooper et al. (2014) confirmed the earlier findings and noted that firms that pay their CEOs in the top $10 \%$ did worse than others and that those companies lost more the longer the CEO was on the job. The question is why? These authors suggest it is a matter of overconfidence.

Announcing large pay packages, boards often refer to incentives and performance (past or expected). For example, Nike spokeswoman Mary Remuzzi said (referring to CEO Mark Parker's 2012 pay of $\$ 35.2$ million, which was 1,050 times the median employee's salary), "The compensation package is designed to attract and retain top talent, reward business results and individual performance. The bulk of the salary is incentive-based and tied to future financial results of Nike, which in turn maximizes shareholder value" (Morais \& Kakabadse, 2014, p. 382). Sometimes compensation also 
considers the comparative value as understood by compensation committees in order to demonstrate the board's faith in their choice and to signal to the industry or the investment community that a promising and very profitable future is in sight. Sometimes, the large packages are simply a product of the power of individual negotiators. Just how are CEOs evaluated, and what are the performance measures that account for their actual behavior? Most answers focus on financial returns, profits, share price, earnings per share, return on investment, and so on. While the influence of the CEO is felt in the construction of these results, it is not entirely within the individual's capacity to singlehandedly influence these data.

Stop and Think: Measures are needed, nevertheless; so if you were a board member, what would you do? Consider the types of compensation, the realities of organizational life, markets, the position of any of the company's products or services in the competitive landscape, and the condition of the organizational ecosystem in which it operates. Be prepared to discuss some ideas about the components of your performance evaluation for the CEO and evidence supporting your case. How might athletes, entertainers, and best-selling authors' performance be calculated similarly, or must theirs be calculated differently?

Management textbooks will tell you that money is not the best motivator, not when you are looking for creativity, excellence, imagination, job competency, or even long-term job satisfaction. It seems that money may even negate intrinsic motivation or lead to demotivation. Money in the amounts given to CEOs has a different meaning that more closely resembles the symbolic value or even speaks to the narcissism of the CEO. Famously, Fortune magazine noted on its November 13, 2000, cover, "Larry Ellison is sick of playing second banana to Bill Gates. So what's his plan to become No.1-the next 'richest man in the world'?" (Huey, 2000). This is purely about bragging rights and symbolic value and has nothing to do with an attempt to "motivate" Ellison to do better next year. A CEO will not change his skill set, think differently, or bring more insight to the performance of his job simply because the money is greater or the stock options more plentiful. It might, however, serve as an incentive to attract him to your company-if, of course, you can convince him to leave the company he founded! On the other hand, if what a CEO is doing is so good, you do want to please the incumbent but, at the same time, manage the compensation in the best interests of the stockholders. One problem, however, is sticking with the same levels of excess (as in Ellison's case) because the precedent has been set. Here, it is not about performance but a personal competition. The value of the actual compensation is relative.

Stop and Think: Consider your own motivation to do well. How is it influenced by the financial payoff? What else seems to motivate you when you find things going well? How do you explain it? How might motivation theorists help explain what would work or not in motivating workers? CEOs? In motivating yourself?

\section{International}

Excessive pay is a major problem in the United States, but less so as we look internationally. Table 1 highlights some of the industrial world's comparative position. 
Table 1. Average CEO Versus Average Worker Compensation (in U.S. Dollars)

\begin{tabular}{|c|c|c|c|}
\hline Rank & Country & $\begin{array}{c}\text { Average } \\
\text { CEO } \\
\text { Compensation }\end{array}$ & $\begin{array}{c}\text { Average } \\
\text { Worker } \\
\text { Compensation }\end{array}$ \\
\hline 1 & United States & $12,259,894$ & 34,645 \\
\hline 2 & Canada & $8,704,253$ & 42,253 \\
\hline 3 & Switzerland & $7,435,816$ & 50,242 \\
\hline 4 & Germany & $5,912,781$ & 40,223 \\
\hline 5 & Spain & $4,399,915$ & 34,387 \\
\hline 6 & Australia & $4,183,419$ & 44,983 \\
\hline 7 & France & $3,965,312$ & 38,128 \\
\hline 8 & United Kingdom & $3,758,412$ & 44,743 \\
\hline 9 & Netherlands & $3,576,256$ & 47,056 \\
\hline 10 & Sweden & $3,358,326$ & 37,734 \\
\hline 11 & Norway & $2,551,420$ & 43,990 \\
\hline 12 & Japan & $2,354,581$ & 35,143 \\
\hline 13 & Denmark & $2,186,880$ & 45,560 \\
\hline 14 & Czech Republic & $2,159,300$ & 19,630 \\
\hline 15 & Poland & 561,932 & 20,069 \\
\hline
\end{tabular}

Note. Source: Table constructed with data obtained from AFL-CIO's (2018) Paywatch.

Perhaps most notably, Japan's CEOs typically receive much less than their status as the third largest global economy would warrant (Kitchen, 2010). But it may be a cultural thing. The ultrahigh salaries are considered unseemly in Japan, where promotion is usually from within, avoiding the public displays that frequently accompany American superstar negotiations to place oneself in an egotistically driven exercise to see just how much one can get away with.

\section{Societal Impact}

There are organizational and societal repercussions of excessive CEO pay. Managers and workers resent the differential, become cynical, and withhold their best performance or their employment turnover spikes. A sense of justice and fairness is undermined. Everyone understands that with increasing skills, experience, and responsibility come additional rewards, but the rewards given the so-called superstars and top executives are so out of line with reasonableness in the public's imagination and experience that subordinates react with an assortment of dysfunctional behavior. According to O'Reilly, director of Stanford University's Center for Leadership Development and Research, at the very least, "...great imbalances sends bad vibes throughout the organization" (Stanford Graduate School of Business, 2007, p. 1).

Stop and Think: What other societal issues arise due to the disparity of income between the CEO and everyone else?

Though the CEO compensation "issue" is an annual event that is accompanied by calls for something to be done about it, even among the most conservative of business journals, the cry simmers down and nothing is done. The Sarbanes-Oxley Act (2002) established regulations in response to the scandals at the turn of the 21 st century, which were supposed to address the issue. Instead of leading to limits to compensation, CEOs were simply motivated to find ingenious workarounds. We conclude the case by returning to where we began, with questions. 


\section{Additional Discussion Questions}

Many questions are embedded in the case that first stimulate the reader to engage with the case while reading it. They also help students prepare for class discussion where there could be a debatestyle activity about (a) the growing inequality; (b) the reasons for the negative relationship between pay and performance; (c) the absolute size of the paycheck and what should be done about it, if anything; or (d) whether or not the system of allocating CEO pay is responsible from shareholders' (owners') and societal perspectives.

There are various methods to determine CEO pay. Which one most fairly represents annual earnings? Do organizations' annual earnings tell the whole story? How does an organization justify the enormous retirement or golden parachute payouts that sometimes dwarf the CEO's actual compensation? What other consequences are there of such exaggerated absolute income figures? How might you explain the exit packages even when CEOs were objectively ineffective, such as Ron Johnson at JCPenny? How might you consider the research that demonstrated a negative relationship between pay and performance if you were to establish a pay package for an incoming CEO at a large company? What about a smaller or private company?

\section{Teaching Notes}

This is an extremely versatile case to teach at all levels due to the nature of the two central issues: the disconnect between pay and performance, which defies the idea of a meritocratic system, and the injustice of such a large disparity between top executives and everyone else. There is so much written on the subject that each student will easily be able to discover additional materials to support or refute any position they hold. This is a perfect case for a "flipped classroom" in which students are responsible for learning content on their own, whereas the classroom is used to discuss questions, solve problems, and debate different sides of an argument. Due to the usually lopsided normative belief that pay is out of control, it may be advantageous to insure that some students take each side of a question for the sake of having a lively classroom discussion and helping them develop their critical thinking skills. This will work in either online or face-to-face situations.

\section{References}

Adams, S. (2014, June 16). The highest paid CEOs are the worst performers, new study says. Forbes. Retrieved from http://www.forbes.com/sites/susanadams/2014/06/16/the-highest-paid-ceosare-the-worst-performers-new-study-says/

American Federation of Labor and Congress of Industrial Organizations (AFL-CIO). (2018). Paywatch. Retrieved from https://aflcio.org/paywatch

Bose, N. (2017). Wal-Mart CEO's compensation rises to $\$ 22.4$ million. Business News. Retrieved from https://www.reuters.com/article/us-walmart-compensation-proxy/wal-mart-ceoscompensation-rises-to-22-4-million-idUSKBN17M2PU

Box Office Mojo. (2018). Black panther. Retrieved from $\mathrm{http} / / / \mathrm{www}$.boxofficemojo.com/movies/?id=marvel2017b.htm

Charter Communications. (2018). Charter announces fourth quarter and full year 2017 results [Press release]. Retrieved from https://newsroom.charter.com/press-releases/charter-announcesfourth-quarter-and-full-year-2017-results/ 
CNN Money. (2002, September 6). Divorce duel reveals Welch's perks. Retrieved from http://money.cnn.com/2002/09/06/news/companies/welch_ge/

Coogler, R. (Director), Feige, K., \& Grant, D. J. (Producers). (2018). Black panther [Motion picture]. United States: Walt Disney Studios.

Cooper, M. J., Gulen, H., \& Rau, P.R. (2014). Performance for pay? The relation between CEO incentive compensation and future stock price performance. Retrieved from http://papers.ssrn.com/sol3/papers.cfm?abstract_id=1572085

Cremers, M., \& Grinstein, Y. (2014). Does the market for CEO talent explain controversial CEO pay practices? Review of Finance, 18, 921-960. doi:10.1093/rof/rft024

Drucker, P. (1977, May 23). Is executive pay excessive? Wall Street Journal. Retrieved from https://www.wagemark.org/pdf/WSJ_Drucker_execpay.pdf

Economic Policy Institute. (2018). State of Working America Data Library: Annual, weekly, and hourly wages and work hours. Retrieved from https://www.epi.org/data/\#?subject=hours

Gunter, C. (2017). How big is the federal workforce, really? FCW. Retrieved from https://fcw.com/articles/2017/10/05/federal-workforce-volker-size.aspx

Haydon, T. (2014, August 26). Woman who worked in four jobs, overcome by fumes, dies as she naps in car. The Star Ledger. Retrieved from http://www.nj.com/union/index.ssf/2014/08/deceased_woman_in_elizabeth_worked_four_jobs_ napped_in_car_overcome_by_fumes_police_say.html\#incart_river

High Pay Centre. (n.d.). Global CEO appointments: A very domestic issue. Retrieved from http://highpaycentre.org/files/CEO_mobility_final.pdf

Huang, J., \& Russell, K. (2017). The highest-paid C.E.O.s in 2016. The New York Times. Retrieved from https://www.nytimes.com/interactive/2017/05/26/business/highest-paid-ceos.html

Huey, J. (Ed.). (2000, November 13). Fortune. New York, NY: Time.

Janssen, S. (Ed.). (2018). World almanac and book of facts, 2018. New York, NY: Simon and Schuster.

Kitchen, M. (2010, July 6). Japan's executive worker pay gap narrows: Report. Market Watch. Retrieved from http://www.marketwatch.com/story/japans-executive-worker-pay-gapnarrows-report-2010-07-06/print

Lin, D., Kuo, H. C., \& Wang, L. H. (2013). Chief executive compensation: An empirical study of fat cat CEOs. International Journal of Business and Finance Research, 7, 27-42.

List of Marvel Cinematic Universe films. (n.d.). In Wikipedia. Retrieved May 8, 2018, from https://en.wikipedia.org/wiki/List_of_Marvel_Cinematic_Universe_films

Living Wage Calculator. (2018). Living wage calculation for Seattle-Tacoma-Bellevue, WA. Retrieved from http://livingwage.mit.edu/metros $/ 42660$

Lorsch, J. W., \& Khurana, R. (2010, May-June). The pay problem: Time for a new paradigm for executive compensation. Harvard Business Review, 112, 30-35.

Masunaga, S. (2015, August 25). What's the top CEO-to-worker pay gap? 1,951 to 1, study says. Los Angeles Times. Retrieved from http://www.latimes.com/business/la-fi-ceo-pay-gap-20150825story.html 
McGregor, J. (2017, June 7). The number of women CEOs in the Fortune 500 is at an all-time highof 32. Washington Post. Retrieved from https://www.washingtonpost.com/news/onleadership/wp/2017/06/07/the-number-of-women-ceos-in-the-fortune-500-is-at-an-all-timehigh-of-32/?noredirect=on\&utm_term=.a9d096232548

Minimum-wage.org. (2018). New Jersey minimum wage for 2017, 2018. Retrieved from https://www.minimum-wage.org/new-jersey

Morais, F., \& Kakabadse, N. K. (2014). The corporate Gini Index (CGI) determinants and advantages: Lessons from a multinational retail company case study. International Journal of Disclosure and Governance, 11, 380. doi:10.1057/jdg.2014.4

Moton, M. (2018). The 10 highest paid coaches in the NFL. Bleacher Report. Retrieved from http://bleacherreport.com/articles/2755442-the-10-highest-paid-coaches-in-the-nfl

Pomerantz, D. (2014, July 21). Robert Downey, Jr. tops Forbes list of top earning actors with $\$ 75 \mathrm{~m}$ take. Forbes. Retrieved from http://www.forbes.com/sites/dorothypomerantz/2014/07/21/robert-downey-jr-once-again-topsforbes-list-of-top-earning-actors/

Profile: Cristiano Ronaldo. (2017, June). Forbes. Retrieved from https://www.forbes.com/profile/cristiano-ronaldo/?list=athletes

Sanchez, C. (2013, September 22). The sad death of an adjunct professor sparks a labor debate [Audio file]. NPR. Retrieved from http://www.npr.org/2013/09/22/224946206/adjunctprofessor-dies-destitute-then-sparks-debate

Sarbanes-Oxley Act of 2002. Pub.L. 107-204, 116 Stat. 745. Retrieved from https://www.gpo.gov/fdsys/pkg/PLAW-107publ204/html/PLAW-107publ204.htm

Stanford Graduate School of Business Staff. (2007, April 1). A wage imbalance between the CEO and workers sends a bad message. Insights by Stanford Business. Retrieved from https://www.gsb.stanford.edu/insights/wage-imbalance-between-ceo-workers-sends-badmessage

Swarns, R. L. (2014, September 28). For a worker with little time between 3 jobs, a nap has fatal consequences. The New York Times. Retrieved from https://www.nytimes.com/2014/09/29/nyregion/3-jobs-plenty-of-dreams-and-the-fatalconsequences-of-one-dangerous-decision.html

Walmart. (2018). Our business. Retrieved from http://corporate.walmart.com/our-story/our-business/

Whedon, J. (Director), \& Feige, K. (Producer). (2015). Avengers: Age of Ultron [Motion picture]. United States: Walt Disney Studios.

Wile, R. (2012, January 15). These CEOs got paid $\$ 100+$ million each to quit. Business Insider. Retrieved from http://www.businessinsider.com/the-21-largest-golden-parachutes-of-the-newmillenium-2012-1?op=1

The Journal of Social Change, sponsored by Walden University, welcomes manuscripts focusing on interdisciplinary research in social change that improves the human condition and moves people, groups, organizations, cultures, and society toward a more positive future.

Walden University Publishing: http://www.publishing.waldenu.edu 